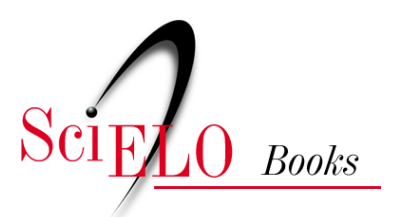

\title{
Povos indígenas
}

\author{
José Carlos Radin \\ Gentil Corazza
}

\section{SciELO Books / SciELO Livros / SciELO Libros}

RADIN, J.C., and CORAZZA, G. Povos indígenas. In: Dicionário histórico-social do Oeste catarinense [online]. Chapecó: Editora UFFS, 2018, pp. 121-127. ISBN: 978-85-64905-65-8. https://doi.org/10.7476/9788564905658.0030.

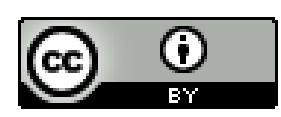

All the contents of this work, except where otherwise noted, is licensed under a Creative Commons Attribution 4.0 International license.

Todo o conteúdo deste trabalho, exceto quando houver ressalva, é publicado sob a licença Creative Commons Atribição 4.0.

Todo el contenido de esta obra, excepto donde se indique lo contrario, está bajo licencia de la licencia $\underline{\text { Creative Commons }}$ Reconocimento 4.0. 


\section{Povos indígenas}

Ao longo de sua história, o território do Oeste catarinense sempre esteve marcado por múltiplas dimensões culturais, que resultaram dos conflitos e da convivência de grupos sociais, como os povos indígenas, caboclos, colonos e quilombolas, que ali conviveram e ainda hoje disputam a terra como meio básico de sobrevivência. Muitos desses conflitos continuam vivos, especialmente o relacionado com a demarcação das terras indígenas (D’ANGELIS, 2006).

Os povos indígenas, que há muitos séculos habitaram o território do Oeste catarinense, pertenciam a dois grupos linguísticos, o grupo Jê e o grupo Tupi. Ao primeiro grupo pertenciam os índios Kaingang e os Xokleng, preponderantes na região. Já os índios Guarani pertenciam ao grupo linguístico Tupi.

De acordo com pesquisas arqueológicas recentes, o processo de povoamento indígena do território do Oeste catarinense pode ser dividido em três fases. Numa primeira fase, ocorrida há cerca de $12 \mathrm{mil}$ anos, teriam aportado à região povos caçadores e coletores nômades. Depois, por volta de 2.500 anos, teriam chegado os povos de língua Jê, provavelmente vindos de regiões centrais do Brasil. Finalmente, a última fase migratória, formada pelos povos tupi-guaranis, oriundos da Bacia Amazônica, teria chegado por volta de 2 mil anos atrás. Essas informações desmentem o argumento propalado pelos colonizadores antigos e modernos de que encontraram um território "vazio" ou um "deserto", pois este território já estava fortemente ocupado de longa data. A historiografia tradicional, de modo geral, colocou as populações indígenas na condição de invisíveis, por não contemplá-los em seus estudos ou por fazê-lo de forma marginal, em geral vendo-os como parte da natureza a ser dominada e conquistada. Na região, assim como na América, a conquista do território já ocupado pelos povos indígenas significou um verdadeiro genocídio, uma vez que eles foram praticamente dizimados pelas guerras, epidemias trazidas pelos colonizadores, como a gripe e varíola, e mesmo pela escravização. 
As primeiras expedições de reconhecimento e conquista dos territórios indígenas do Oeste catarinense começam a chegar ainda no século XVI. A primeira delas teria sido chefiada pelo conquistador espanhol D. Álvar Nuñes Cabeza de Vaca, governador geral do vice-reinado espanhol da região do Prata, que partiu da Ilha de Santa Catarina, entre 1541 e 1542, atravessou o território até chegar a Assunção. Poucos anos depois, entre 1552 e 1553, foi o militar alemão Ulrich Schmidel, que teria atravessado o Peperi-Guaçu e chegado à margem direita do Rio Uruguai, aproximadamente na região atual de Palmitos. Nos séculos XVII e XVIII, chegaram os jesuítas vindo do Paraguai e, em seguida, os bandeirantes vindos de São Paulo. Eles atacaram as reduções jesuíticas e levaram mais de 60 mil indígenas escravizados para São Paulo. No início do século XIX vieram os fazendeiros para ocupar os campos de Guarapuava e de Palmas, visando à criação de gado. A ocupação desses campos, que na sua maior parte representa o atual território do Oeste catarinense, era tida como vital para a geopolítica do Império, em face às disputas territoriais com a Argentina.

Os povos indígenas que habitavam a região eram preponderantemente os Kaigangs e Xoklengs, pertencentes ao grupo Jê. A relação dos invasores com os diversos povos indígenas era uma relação entre colonizador e colonizado e implicava uma situação de exploração contínua, nem sempre facilmente perceptível, desde o passado até o presente, mas que implicou a expropriação de suas terras, de suas vidas e de sua cultura. As reações dos povos indígenas aos invasores foram diferenciadas, envolvendo desde certa convivência, como a dos Guaranis e relações ambíguas de aceitação e beligerância como foi o caso dos Kaingangs, liderados pelo cacique Condá e Xoklengs (MALAGE, 2010). Na realidade, não restavam muitas alternativas aos povos indígenas frente aos invasores de suas terras, pois representavam a parte mais fraca e vulnerável nessa relação. Podiam aceitar a ocupação e integrar-se à forma de vida dos colonizadores, aldeando-se em vilas, o que lhes garantia alguma condição de sobrevivência, fugir de suas terras, abandonando tudo o que possuíam, ou resistir e serem escravizados ou simplesmente eliminados, como acabou acontecendo com a maior parte da população indígena. 
Por sua vez, as políticas oficiais em relação aos povos indígenas evoluíram desde a defesa da integração na sociedade brasileira, do que sobrou desses povos, após a ocupação de suas terras, até uma política de aldeamento e demarcação de terras indígenas, o que em princípio daria mais condições de sobrevivência e preservação de sua cultura e do seu modo de vida.

No entanto, o contato com os homens brancos, seu modo de vida e seus valores, resultou em um processo de desintegração econômica, social e cultural dos povos indígenas, desarticulando o seu sistema de vida tribal e comunitário, contaminando o grupo com doenças até então desconhecidas, sem que os indígenas oferecessem qualquer resistência biológica.

Atualmente existem diversas reservas indígenas no Oeste catarinense, destacando-se a Condá, em Chapecó, o Toldo Imbu, em Abelardo Luz, o Toldo Chimbangue, em Chapecó, o Xapeco, em Ipuaçu e Entre Rios e Toldo Pinhal, em Seara. Essas reservas são essencialmente de indígenas da tribo Kaingang. Já os indígenas da tribo Guaraní ocupam outras reservas semelhantes na região.

\section{REFERÊNCIAS}

BRIGHENTI, Clovis Antonio. Povos indígenas em Santa Catarina. Disponível em:

$<$ https://leiaufsc.files.wordpress.com/2013/08/povos-indc3adgenas-emsanta-catarina.pdf $>$. Acesso em: 3 abr. 2017.

D’ANGELIS, Wilmar da Rocha. Para uma história dos índios do oeste catarinense. Chapecó, Cadernos do CEOM, Ano 19, n. 23, 2006 - CEOM: 20 anos de memórias e histórias no Oeste de Santa Catarina.

MALAGE, Kátia Graciela J. M. Condá e Viri: chefias indígenas em PalmasPR, década de 1840. (Dissertação de Mestrado). Curitiba: UFPR, 2010. 